\section{The Publisher Gabriel Giolito de' Ferrari, Female Readers, and the Debate about Women
in Sixteenth-Century Italy and the Debate about Women
in Sixteenth-Century Italy}

Cet article examine les stratégies de publication que l'éditeur vénitien du XVIe siècle, Gabriel Giolito de' Ferrari et ses collaborateurs, ont appliquées dans le but d'attirer le lectorat féminin pour des ouvrages impliqués dans la controverse dite "querelle des femmes", des ouvrages de Giovanni Boccaccio et de littérature de dévotion. Notre attention se penche particulièrement sur les dédicaces d'ouvrages qui s'adressent couramment aux femmes en les qualifiant de lectures idéales pour les femmes, et en présentant systématiquement Giolito comme un défenseur dévoué des femmes. Cet article examine si les tactiques de Giolito attiraient effectivement les femmes ou si elles étaient plutôt destinées aux cercles d'hommes s'identifiant au rôle en vogue de "défenseur des femmes ». On y retrace aussi avec quelles significations culturelles Giolito considérait chacun de ces livres et les changements qu'ont subit les titres et le public en lien avec le passage de son intérêt pour la littérature défendant les femmes et les ouvrages de Boccaccio, qui ont dominé les années 1540 et 1550, vers des ouvrages de littérature de dévotion pour les femmes en lien avec le climat post-Tridentin de la deuxième moitié du XVI siècle. À travers l'examen de la présentation matérielle et des prix de ses ouvrages, cet article propose des observations au sujet des besoins et des pratiques de lecture concernant chaque genre littéraire en question. Enfin, cet article met en lumière un aspect important de la dynamique sociale entourant la controverse des femmes de l'Italie du XVIe siècle, à savoir le rôle des femmes comme lectrices et actrices de la culture.

Gabriel Giolito de' Ferrari, one of the most prominent publishers in the
sixteenth-century dynamic Venetian publishing industry, is well known
for his ability to adapt to the book market and successfully respond to the
broader reading public's demands by collaborating with talented professional
writers and publishing vernacular literature for the lay reader. ${ }^{1}$ This study
discusses the publishing strategies Giolito and his collaborators adopted to
appeal (with questionable candour) to a female readership in books relating 
to the controversy about women - also known as the querelle des femmes_-2 in Giovanni Boccaccio's works and in devotional literature. Giolito became one of the most important contributors to the debate about women on the women's side in Italy, publishing some of the earliest works on the topic. ${ }^{3}$ Nor was his interest in the woman question limited to his publishing choices. Addressing female readers and contemporary powerful women in his proems and dedications, he persistently presented himself as a devoted defender of women and promoted his books as significant contributions to women's vindication. Furthermore, Giolito published the works of well-known Italian women writers, such as Tullia d'Aragona, Laura Terracina, and Vittoria Colonna. ${ }^{4}$ Nevertheless, Giolito's contribution to the querelle des femmes remains unexplored. This essay traces the cultural meaning(s) with which Giolito invested each book, along with the changes his titles and public profile underwent throughout the sixteenth century as his interest shifted from literature defending women and Boccaccio's works, which dominated in the $1540 \mathrm{~s}$ and $1550 \mathrm{~s}$, to vernacular devotional literature for women in the postTridentine climate of the later sixteenth century.

Drawing on recent work on the social history of the book and the politics of reading, this essay considers the texts under question as social products, whose meaning is not just determined by the author's initial intentions, but is further shaped in the process of production, dissemination, and reception as a result of negotiation among several parties in a given historical moment. ${ }^{5}$ A close examination of Giolito's case suggests that not only authors but also publishers, editors, translators, the social elite as literary patrons / patronesses, and the communities of readers (both male and female) all participated, though perhaps not equally, as cultural agents in the formation and development of the controversy about women, both appropriating the dominant discourse and further formulating it. ${ }^{6}$ In this view Giolito's publishing strategies, reflected both in the books' verbal elements (proems, dedications, title pages) and material form (format, size, and price) and in the shaping of the publisher's public image, have to be seen as conveyors of meaning imbued with cultural values which were simultaneously recognizable by Giolito and his collaborators, the dedicatees, and the communities of readers. Thus, Giolito's case can contribute to a better understanding of the early modern controversy about women, the changes it underwent throughout the sixteenth century in relation to the establishment of the Catholic Reformation, and the complex interplay among the mechanisms of book production, the dominant discourse about women, and women's formulation and appropriation of this discourse as readers in sixteenth-century Italy. 
Before proceeding to examine both Giolito's handling of the controversy about women and his publishing strategies towards female readers, it will be necessary to outline how the Giolito company fitted into the sixteenth-century Venetian publishing industry. Gabriel Giolito's career as a publisher began when his father Giovanni transferred the publishing house he had first established in their homeland, Trino, near Casale Monferrato, to Venice in $1536 .{ }^{7}$ After his father's death in 1539, Gabriel continued on his own, and from 1541 only his name appears on the title page. Between the years 1550 and 1556 he was joined by his brothers. He then worked alone until 1578, when his sons Giovanni and Giovanni Paolo undertook the business until $1606 .{ }^{8}$ On his arrival in Venice, Giolito confronted a dynamically emerging publishing industry and a strongly competitive book market. Thanks to its lively intellectual life and economic prosperity, and to the effective exploitation of the printing press (enabling large production with relatively low manufacturing costs), Venice had, by the late fifteenth century, become one of the most important centres of publishing. It supplied readers all over Italy and even abroad, and offered the best opportunities to individuals who wished to be involved in the new, profitable industry. Well-known publishing companies such as those of Giovanni Andrea Valvassori, Francesco Marcolini, Vincenzo Valgrisi, Michele Tramezzino, Giovanni Griffio, and of course that of Gabriel Giolito, were all set up in Venice during the 1530s and 1540s. ${ }^{9}$ It has been estimated that probably surpassing their European rivals in Lyon, Paris, and Basel, the Venetian presses published at least 15,000 editions in the sixteenth century. ${ }^{10}$ Literati and bookmen from all over Italy and abroad gathered in Venice-passing on their experiences to the city's cultural environment. As a crossroad between northern Europe, Italy, and the East, and equipped with such a successful publishing industry, Venice was a significant centre for intellectual association and traffic of ideas.

A factor of equal importance for the development of the book market was the gradual replacement of Latin by the vernacular, both as a consequence of the invention of printing and as a necessary precondition for its further development. Treatises on language, such as Pietro Bembo's Prose della volgar lingua (1516), and vernacular classics, such as Baldesar Castiglione's Il Cortegiano (1528) and Lodovico Ariosto's Orlando Furioso (1516), were instrumental in the standardization of the vernacular, establishing fourteenthcentury Tuscan, especially Petrarch and Boccaccio, as the model for the Italian literary language. Bookmen and literary agents in Venice furthered the establishment of the vernacular, translating Latin texts into Italian, releasing treatises on the proper use of the vernacular, and largely circulating the writings of Petrarch, Boccaccio, and Ariosto enriched with the editors' linguistic 
commentaries. The bookmen's goal was the greatest possible increase in the reading public, which included now less-educated male readers and women, as is often indicated by the proems and dedications of the emerging literature. The establishment of the vernacular and the popularization of the written culture were of vital importance for expanding the publishing trade. The relatively low prices of books, often published in octavos and duodecimos, and the promotion of new topics, which would attract the new reading public, were of equal importance. ${ }^{11}$

In this context Gabriel Giolito's publishing strategies can be better understood. Seeking to attract a broader reading public, Giolito collaborated with talented professional writers, the so-called poligrafi-who worked as translators, editors, proofreaders, and writers of "best-sellers" 12 - and promoted vernacular literature, avoiding Latin or specialized titles. His editions were often enriched with annotations and commentaries for the help of the less experienced reader (especially in the texts of Petrarch, Boccaccio, and Ariosto). ${ }^{13}$ Furthermore, Giolito offered low prices in comparison to other publishers. Under the Giolito press the average price per piece between the years 1549 and 1591 was 1 lira and 16 soldi, whereas in the Aldine press in 1592 it was 3 lire and 8 soldi. ${ }^{14}$ To adapt better to the book market, Giolito published books in different qualities; the most expensive in quarto format and italic type, the less expensive in octavo format and usually in roman type, and the cheapest ones in duodecimo and sextodecimo. As well as his own bookstore, called Libreria della Fenice (the phoenix was his printing device), in Rialto, Venice's mercantile centre, Giolito maintained bookstores in Ferrara, Bologna, and Naples, supplying readers all over Italy. ${ }^{15}$ As this study intends to show, Giolito's good knowledge of current cultural trends and well-planned shaping of his public image were equally significant to his success.

Giolito made his debut in the controversy about women in 1544 with Della nobiltà et eccellenza delle donne, a translation of Henricus Cornelius Agrippa von Nettesheim's Declamatio de nobilitate et praecellentia foeminei sexus. ${ }^{16}$ Published in 1529, Agrippa's well-documented defence of women had been translated from Latin into French (1530), German (1540), and English (1542), and had been established, along with Baldesar Castiglione's third book of Il Cortegiano (1528), as a major contribution to the early modern controversy about women. Giolito's translation, however, was not the first publication in Italian of Agrippa's treatise. Another obscure translation indicating neither the publisher nor the translator had appeared around 1530, probably in Venice. ${ }^{17}$ 
A comparison between the preliminary materials of the two editions interestingly indicates the self-image Giolito wished to fashion. ${ }^{18}$ Whereas the 1530 translation clearly acknowledged Agrippa as the original author, and kept intact the initial dedication to Margaret of Savoy, Princess of Austria and Burgundy, Giolito's translation made no reference to the author either on the title page or in the main text. Similarly, the dedicatee's name was eliminated and Giolito dedicated the work to Buona Maria Suarda da San Giorgio, a noblewoman from Monferrato, Giolito's homeland. Not acknowledging the author, Giolito apparently sought to play down the authorship and stress his own role instead. It was a strategy Giolito would adopt systematically in the following years. Giolito's self-presentation as the leading figure in the undertaking is further demonstrated by the secondary position the translator's name held. The translation appeared in two different versions in 1544 and both indicated on the title page that the translation had been done from French into Italian ("dalla lingua francese nella italiana tradotto"). Only one version, however, indicated a certain Francesco Coccio as the translator ("tradotto per Francesco Coccio"). With the author absent and the translator's role downgraded, Giolito emerged as the work's main contributor.

The absence of the dedicatee's name from the title page is also indicative of her secondary place in the undertaking. Defences of women were frequently dedicated to powerful women, and their contributions were often underlined by the mention of their names on the title page, ${ }^{19}$ especially when the author was offered hospitality at their courts. Although the commercialization of the written culture after the spread of printing gradually created new economic relations - replacing the traditional patronage mechanisms of the courts and Church with the book market forces - patrons continued to play an important role in the literary production, contributing to the manufacturing costs or lending prestige to the work with their prominent names. ${ }^{20}$ However, Giolito was dependant not so much on the help of patrons as on the responses of readers. ${ }^{21}$ Although Buona Maria Suarda may have contributed financially to the translation, the main investor was apparently Giolito. ${ }^{22}$ With his dedication to an important woman of Monferrato, Giolito rather wished to praise his homeland, with which both he and later his sons continued to maintain close relations, as their dedications to important figures of Casale and Monferrato indicate. Furthermore, by choosing a female dedicatee Giolito made it clear that the book was meant for female readers, a pattern also common in the following years.

Giolito begins his dedication in the usual way of praising the dedicatee. He dedicates "questa opera, la quale parla della eccellenza delle Donne" (this work which deals with women's excellence) to Buona Maria Suarda, 
since her virtue "fu sempre una, \& delle maggiori difese delle Donne" (has always been unique, and one of the greatest defences of women). Then he brings forward the motifs which were to feature in subsequent titles: loyalty to women, an attack on women's adversaries, and the production of books for the benefit of women. His translation would make women's "nemici che sono usati biasmarvi, e portarvi invidia" (adversaries who are in the habit of blaming and envying you [women]), acknowledge "quei gradi di perfettione, \& quei termini di grandezza, iquali meritamente pongono in honore \& riverenza le Donne appresso gli huomini di giuditio" (those degrees of perfection and those terms of greatness which deservedly make wise men honour and revere women). Giolito also states that the work is not only his gift to Buona Maria Suarda but also "porto generalmente al sesso vostro" (a harbour for your [women's] sex generally). Shifting the focal point from the dedicatee to all women and underlining the work's formative influence on the public opinion in favour of women, Giolito invested his endeavour with a social reference.

Soon after the publication of Della nobiltà, Buona Maria Suarda sent a letter of thanks to Giolito. Although she referred to the author with gratitude, she did not mention Agrippa by name. Following Giolito's schema, she underlined the work's beneficial effect for women, and acknowledged Giolito's devotion to them:

... tutte le donne, le quali, poi che mercè del bel ingegno ... si veggono antiposte a gli huomini; mi pare bene honesto, che tutte insieme devriano tanto affaticarsi in renderne gratie a chi ha scritto per loro ... son certa, che pel vostro esser devoto del sesso donnesco, non s'è la bontà d'Iddio dimenticata di darvi qualche merito ... ${ }^{23}$

... all women, who, thanks to this ingenious author ... have been put before men; it seems very honest to me that all [women] together should have concerned themselves with expressing their gratitude to him, who wrote it for them ... I am sure that God Almighty has not forgotten to reward you for your devotion to the female sex ...

The translation of Agrippa's work was soon published again. The 1545 and 1549 editions were enriched with L'orazione in lode delle donne, an oration praising women, which the humanist and philosopher Alessandro Piccolomini had delivered in the Academy of the Intronati in Siena. ${ }^{24}$ In 1545, Piccolomini had already acquired the reputation of the "defender of women." In his Dialogo della bella creanza delle Donne (1539), also known as Raffaella, Raffaella, an old woman of humble origins, persuades the young Sienese noblewoman Margarita to enjoy a life of indulgence and find a lover unbeknown to her husband on the grounds that she got married against her will. ${ }^{25}$ The Dialogo has often been seen as a mere comedy intending to demonstrate women's weak, vainglorious, and lascivious nature. ${ }^{26}$ 
However, a closer examination in the light of the Renaissance tradition of the "serio-comic" 27 reveals arguments favouring women, such as Piccolomini's denunciation of women's marriage against their will, and his criticism of the different way contemporary society dealt with men's and women's conjugal infidelity, tolerating the former and condemning the latter. ${ }^{28}$ Prowoman arguments also feature in Piccolomini's De la institutione di tutta la vita de l'huomo nato nobile e in città libera (1542). Shifting from the typical Neo-Platonic perception of women as the means for men's perfection, Piccolomini stressed women's active role in love affairs. ${ }^{29}$ Giolito must have come in contact with Piccolomini when the latter was in Padua in the early 1540 s, participating in the activities of the University and the Academy of the Infiammati. ${ }^{30}$ By including the oration which a well-known intellectual, associated with the Venetian literary environment, had delivered in an eminent Academy, Giolito lent prestige to the work and adjusted the translation to the Italian intellectual environment.

In 1545, Giolito published the Dialogo della institution delle donne secondo li tre stati, che cadono nella vita humana, by the poligrafo Lodovico Dolce, a close collaborator; it was republished in 1547, 1553, and 1560. Actually, it was a close adaptation of the Spanish humanist Juan Luis Vives's well-known De institutione feminae Christianae (1524), ${ }^{31}$ one of the first works exclusively treating women's education and proper conduct. Vives's treatise quickly became very popular throughout Europe, being translated into English, Dutch, French, German, and Italian (an original Italian translation by Pietro Lauro was published by Vincenzo Valgrisi in 1546). Although not directly dealing with the woman question, Vives rebutted the broadly held view that women were unable to engage in letters, but he still drew a sharp division between women's and men's educational needs, stressing that women's education aims at the safekeeping of their chastity and not at a public life. ${ }^{32}$ Following most of Vives's arguments and structure (three parts treating virginity, married life and widowhood respectively), Dolce transformed the treatise into the popular Italian genre of dialogue (between two fictional characters, Flaminio and Dorothea) and enriched it with specific Italian references and current events, such as a debate on marriage which is supposed to have taken place in Pietro Aretino's house among Aretino, Fortunio Spira, Paolo Stresio, and the author. However, the most interesting difference between Vives and Dolce is found in their views on the appropriate reading for the young woman. Vives's strong rejection of vernacular literature as immoral and lascivious could not have been adopted by Dolce-who approves non-lascivious vernacular literature, especially Petrarch and Dante. ${ }^{33}$ Dolce's main concern as a poligrafo and a collaborator of Giolito was to maximize 
the demand for vernacular literature by both men and women. It is probably within this context that Dolce also omitted the term "Christian" from the title in order to have greater latitude for initiative.

Following the same tactic as with the translation of Agrippa's work, Giolito and Dolce nowhere acknowledged Vives's authorship in the text. On the contrary, Giolito underlined the work's originality, noticing that until then no book had properly laid down particular rules for women's conduct, and describing Dolce's method in the process of writing. Again Giolito's dedication addressed a woman from his homeland, Violante da San Giorgio from Casale Monferrato. Echoing Vives's views on education, Giolito stresses the importance of education both for men and women, which is indeed more vital to "il sesso feminile" (the female sex) which is "non cosi forte, come è quello de gli huomini" (not so strong as that of men). Immediately, however, he modifies his misogynist tone, arguing that with the appropriate education women reach "tanta perfettione, che s'avicinano à quella de gli Angeli" (such excellence that they approach that of the angels). Furthermore, as with the translation of Agrippa's work, Giolito emphasizes his own agency and desire to be useful to women:

Onde havendo molti antichi Scrittori in diversi libri descritti à gli huomini i precetti della vita; nessuno alla Donna havendo (che io sappia) lasciare particolari regole: ho voluto io, per giovar loro, dare in luce il presente Dialogo di Meser Lodovico Dolce: nel quale egli, seguitando in cio il costume delle Api, ha raccolto da molti Philosophi gli ammaestramenti, che appartengono alla buona \& virtuosa vita, che dè tenere una Donna in qualunque stato ...

As many ancient authors have described the precepts of life to men in several books, but no one (as far as I know) has laid down particular rules for women, I wished to be useful to them [women] and bring to light the present dialogue by Mr Lodovico Dolce; following in this the custom of bees, he has picked up many philosophers' teachings in what consists a good and virtuous life that a woman should lead in each state ...

The dedication concludes with reference to women as potential readers: "Havranno adunque le donne nel picciolo volumetto honesti \& santi ammaestramenti: \& in V. S. l'esempio ... le Vergini impareranno da V. S. la purità, le Maritate la fede, \& le Vedove la toleranza \& la castità" (So, women will have honest and devout lessons in this small volume, and the example of Your Majesty ... virgins will learn from Your Majesty purity, married women faith, and widows tolerance and chastity).

In 1548 (also in 1549), Giolito enriched his list of titles relating to the controversy about women with the Lettere di molte valorose donne, nelle quali chiaramente appare non esser ne di eloquentia ne di dottrina alli huo- 
mini inferiori, a collection of letters, written, as the editor Ortensio Lando claims, by women. ${ }^{34}$ The letters' aim is to demonstrate the great learning of these women on a variety of issues: everyday topics, such as the birth of a baby or the death of a beloved person, advice on various matters usually relating to the marriage or family etc. Some letters discuss the problems contemporary women faced in domestic life, especially their sufferings from male relatives, whereas others discuss vexed contemporary issues, such as convent life and enforced claustration, or women's education and its limitations. ${ }^{35}$ The woman question is also discussed in detail. Indicative is Livia d'Arco's letter to Laura Pestalosa. It is a typical defence of women, citing examples of learned and virtuous women of the past to demonstrate that women are superior to men. ${ }^{36}$ Similarly, Beatrice Pia writes from Cattai (Veneto) to Lucia Manfredi, hoping that women will awaken to reclaim their ancient glory since they are not born to serve and obey men. ${ }^{37}$

Although Lando's collection includes no dedication by Giolito, the typical Giolitian patterns emerge again: the contribution to women's vindication, the attack on women's adversaries, and the potential female readership. In his dedication to Sigismondo Rovello (Edmund Harvel), the English ambassador to Venice, Lando asks for the dedicatee's help against "la nequitia de Calunniatori," (the Calumniators' wickedness) so that "le maligne lingue nemiche de gli honori feminili, sbigottite si rimanessero di mordere et di lacerar le Donne" (the malicious tongues, enemies of the female honour, fear to bite and lacerate women) and "imparassero hormai à riverire et honorare questo nobilissimo sesso" (learn now to respect and honour this most noble sex). Verses by Lodovico Dolce, Girolamo Parabosco, Pietro Aretino, Francesco Sansovino, and Niccolò delli Alberti da Bormo, at the end of the volume, address either women readers or Lando, praising Lando for having honoured women and, in Parabosco's words, exonerated them from "quel biasmo, che vi dan le false lingue" (that blame which malicious tongues put on you [women]). ${ }^{38}$

Lando was also a known "defender of women." In the second part of the Forcianae quaestiones (Naples, 1535), written under the pseudonym Philalethe Polytopiensi Cive, Lando discussed female superiority, citing examples of famous women from Antiquity, the Scriptures, and his time. Lando also participated in the controversy about women with the twenty-fifth paradox, entitled Che la donna è di maggior eccellentia che l'huomo, included in his Paradossi, cioè sententie fuori del comun parere (Lyon, 1543). ${ }^{39}$ Furthermore, according to Conor Fahy, Lando was the editor of an anonymous translation from Latin into Italian of the oration defending women which Vincenzo Maggi had delivered before Anna d'Este in Ferrara in 1545. The 
volume, published in 1545, included another treatise on female superiority, entitled Essortatione a gli huomini, also attributed to Lando. ${ }^{40}$ Later works by Lando also refer to women. The Oracoli de moderni ingegni (1550), a collection of adages attributed to "gli piu Illustri Cavallieri, gli piu gravi Senatori, gli piu Reverendi Prelati, \& le piu honorate Donne dell'età nostra" (the most illustrious Cavallieri, the most important Senatori, the most reverend Prelates, and the most prestigious women of our days), ${ }^{41}$ and the Sette libri de cathaloghi (1552), a dictionary of persons famous for their beauty, learning, bravery, evilness, etc, also including female representatives, were both published by Giolito.

In 1549 (also in 1551 and 1552), Giolito published one of the most detailed and complete defences of women, La nobilità delle donne, written by the poligrafo Lodovico Domenichi, Giolito's close collaborator. It was a dialogue between contemporary literary and political figures that took place during the nuptial ceremonies of Muzio and Faustina Sforza in Milan in 1546. In a letter to Bartolomeo Gottifredi, included in the volume, Domenichi cites as his sources Plutarch, Henricus Cornelius Agrippa von Nettesheim, Galeazzo Capra, Lodovico Martelli, Vincenzo Maggi, Baldesar Castiglione, Sperone Speroni, Ieronimo della Rovere, and one "reverendo padre Maestro Zanobi dell'Aiolle, Fiorentino." 42 Hinting at the poligrafi's method, Domenichi writes: “ . . vagando per diversi campi dell'altrui scritture, \& raccogliendo l'openioni \& auttorità di questo, $\&$ di quello auttore antico, $\&$ moderno, nuovamente ho composto la nobilità, et eccellenza delle Donne" (rambling through several fields of others' works and collecting the opinions and authorities of ancient and modern authors, I have composed anew the nobility and excellence of women). Incorporating in a single volume a large number of arguments both for and against women, Domenichi's dialogue epitomized the current controversy over women. Subsequent writers often named Domenichi as one of the most known "defenders of women." 43

In the proem Domenichi declares his faithful devotion to women, attacking "la viltà \& ignoranza di coloro, che le biasimano \& offendono a torto" (the cowardice and ignorance of those who unjustly slander and insult them). Giolito emerges again as an equally leading figure in the undertaking. But now it is Domenichi who shapes Giolito's image as an established defender of women:

Gabriel Giolito hoggimai conosciuto affettionatissimo, et devoto delle Donne, per tutte le sue costumate attioni, spetialmente per procurare ogni di che dalle sue bellissime stampe escano in luce \& nelle mani del mondo le lodi del sesso Donnesco: diche a lui ne vien honore tuttavia, \& guiderdone anchora da quelle. 
Nowadays, Gabriel Giolito is known as a man affectionate and devoted to women, thanks to all his acts of kindness, and especially for his daily effort to bring to light and in people's hands the praise of the female sex with his beautiful publications; from those Giolito has received not only every respect but also reward.

Domenichi implies here that women, most probably some of the dedicatees, had funded Giolito's publications. Although there is no concrete information about such transactions, Giolito certainly anticipated the favour of the dedicatees. However, it is also plausible to suggest that Domenichi may imply here Giolito's profit from a female clientele.

Works relating to the controversy about women constituted only a small part of the Giolito company's large production of more than 1,000 titles. ${ }^{44}$ However, Gabriel Giolito released some of the earliest and most important Italian works on the topic; he can be regarded as a specialist in the genre, issuing more such works than any other contemporary publisher in Italy. Interestingly, Giolito never published Boccaccio's De mulieribus claris, ${ }^{45}$ a collection of biographies of famous women that had already from the fifteenth century made a vital contribution to the controversy about women, since it furnished "defenders of women" with the necessary examples of female virtue and set the example for similar collections of women's biographies throughout Europe. ${ }^{46}$ However, following a long tradition which connected Boccaccio with female readers, Giolito and his collaborators sought to interest women in Boccaccio's works.

Giolito's wish to associate Boccaccio with a potential female readership is already manifested in his dedication of L'amorosa Fiammetta (1542), edited by Dolce, to the "Gentili et Valorose donne della Città di Casale di Monferrato" (Gentle and Valorous women of the city of Casale Monferrato). This early dedication to women conveyed what later became the normative terms of Giolito's advertising techniques. According to Giolito, L'amorosa Fiammetta was ideal feminine reading since it narrated a woman's amorous experiences:

Tra le bellissime Volgari prose dallo eccellente M. Giovanni Boccaccio a vostra consolatione et utilita iscritte; niuna ve n'ha Nobilissime Donne, che piu da voi tenersi cara et apprezzare si debba della presente opera chiamata l'amorosa Fiammetta. Percioche in lei contenendosi i sospiri, le lagrime, \& le lunghe miserie di una innammorata giovane dal suo amante abbandonata.

Among the excellent Giovanni Boccaccio's most beautiful vernacular prose, written for your consolation and utility, most noble ladies, you should consider dearest and most appreciate the present volume, under the title L'Amorosa Fiammetta. Because it 
includes the sighs, tears, and lingering sufferings of a young woman in love, who was abandoned by her lover.

Apart from the diligent editorial attention paid to the text, Giolito proclaims his faithful services to women, and expresses the hope that the dedication and the release of more books for them will attract female readers' interest. Furthermore, he places himself next to the author, anticipating women's acknowledgement:

Perilche io; che a servigi di ciascuna di voi nacqui; havendo questo libro con ogni diligenza fatto correggere et ristampare, ho giudicato convenevole ufficio di mandarlo fuori sotto il nome vostro: accio che piu volentieri leggendolo; se alcun frutto ve ne verrà; non solamente dal suo Autore, ma anchora da me l'habbiate a conoscere ... Percioche l'ornamento delle donne non è riposto nella crudelta, o nella spiacevoleza: et niuna per essere nemica de gli affetti humani fu commendata giamai. Intanto io nell'avvenire cose sempre piu nobili et piu degne vi porgero.

So, I, who was born to be in the service of every one of you, having corrected and republished this book with every diligence, judged that it is a kind duty to issue it in your name so that you read it more voluntarily. If it proves to be fruitful to you, you should recognize not only its author but also me ... Since the ornament of women does not consist in cruelty or wretchedness and no woman has ever been known as enemy of human activities. So, in the future I will always donate the most noble and worthy things to you.

A similar rationale appears in Il Decamerone (1546), edited by Francesco Sansovino. In his dedication to La Delfina di Francia (Caterina de' Medici), Giolito notices that some years earlier he had dedicated Lodovico Ariosto's Orlando Furioso, "corretto, \& di molte belle et utili cose ornato nelle mie stampe" (corrected and adorned with many beautiful and useful things in my press), to Caterina's husband, Henry II of France, for discussing "del valore delle armi, \& della prudenza di virtuoso Prencipe" (the worth of arms and the prudence of the virtuous Prince). But, as Giolito writes, Il Decamerone better suits women since "materie piacevoli contiene, \& per la maggior parte di Donne, \& per cagion di Donne dal suo Autore fu composto" (it contains pleasant matters, and for the greatest part related to women, and it was written by its author for the sake of women). Similarly, Giolito's earlier edition of Il Decamerone (1542) had been dedicated by the editor, Antonio Brucioli, to Maddalena Bonaiunti, Caterina de' Medici's protégée.

In their proems and dedications Giolito and his collaborators meticulously invested each work with the appropriate meanings and determined the interpretation of the content. Indicative is Boccaccio's Laberinto d'amore (Il Corbaccio) (1545) which included a dedicatory epistle by Domenichi to 
Bernardin Merato which ingeniously disassociated the misogynist implications traditionally attributed to the text from the publisher's views, and maintained intact Giolito's desired self-image as a defender of women:

... come disse il Giolito, quando una copia sola di tale opera si fosse al mondo, \& nelle sue mani, forse non era degno di biasmo se l'avesse data alle fiamme, per piacere a questo gratioso sesso: ma poi che tante altre ce ne sono... non è disconvenuto, che la amorevolezza di M. Gabriello si sia impiegata in questa, quale ha fatto nelle altre con quelle lodi che lo rendono famosisimo appresso gli huomini di giudicio.

... as Giolito said, even if there was only one copy of this work in the world, and it was in his hands, maybe he should not be blamed if he burnt it to please this charming sex; but since there are so many copies ... it is not improper that the affectionate Mr Gabriel concerned himself with it, as he has done with other publications as well, with such diligence that renders him most famous to men of judgement.

Giolito and his collaborators expected the Laberinto d'amore to attract readers due to its relevance to the controversy over women, but at the same time Giolito had to show that in this dispute he was on the side of women.

Two main issues emerge as preoccupations of Giolito and his collaborators: the shaping of Giolito's image as a defender of women, and the appeal to a community of female readers. The question, however, remains, whether this appeal was genuine - and thus an aid to our understanding of female readership and its significance for the development of the controversy about women in early modern Italy - or whether it was just a rhetorical device, which, along with Giolito's self-declaration as a defender of women, was mainly intended for a male intellectual community.

Having its origins in courtly rhetoric, the identity of the "defender of women" was part of an exemplary elite masculinity. In Baldesar Castiglione's Il Cortegiano, the defence of women emerges as one of the fundamental social virtues of the ideal courtier. As one of the interlocutors, Bernardo Dovizi, claims, "the courtier should above all show respect and reverence for women"; whereas in Magnifico Giuliano's words, "we each and all of us know that it is fitting for the courtier to have the greatest reverence for women ... I have known few men of worth who do not love and pay tribute to women." 47 However, in the 1540s and 1550s the ideal of defending women gradually spread beyond the narrow limits of court culture, and literati of lower origins who were not associated with court life often fashioned the identity of the defender of women to assert their own noble sentiments and ideals. In his Lettura (1552), Girolamo Ruscelli wrote that "elle [donne] sono amate, riverite, \& servite solamente da i piu veri, e piu perfetti huomini" (they [women] are loved, respected and served only by the most genuine and 
perfect men). ${ }^{48}$ An integral part of this schema was the defenders' opposition to women's adversaries, often identified with the vulgar multitude. According to Sperone Speroni, it is "il volgo ignorante" (the ignorant common people) that "scrive e parla publicamente la donna esser nata irrational creatura, poco meglior delle bestie" (write and claim in public that the woman is born an irrational creature, a little better than the beasts). ${ }^{49}$ Similarly, Lodovico Domenichi states that his defence of women marks him off from "il rimanente del vulgo" (the rest of the common people)..$^{50}$ In their undertaking, defenders of women often allied themselves with powerful women. In his dedication of the Difese delle donne (1552) to Eleonora de' Medici, Duchess of Florence, Domenico Bruni invoked the dedicatee's prestige to protect his work from those who are "poco amici delle donne" (hardly friends of women). Similarly, Tommaso Garzoni asked Margarita Estense Gonzaga, Duchess of Ferrara, to defend Le vite delle donne illustri (1588) from those "mordaci lingue" (biting tongues) which would mock him for "lodar sì apertamente" (praising so openly) women. ${ }^{51}$ Thus, presenting himself as a defender of women, Giolito fashioned an identity which secured him a prominent place in contemporary culture, and appealed to specific circles of intellectuals and male readers who shared the same ideals.

Can Giolito's appeals, however, be simultaneously associated with women's reading preferences and expectations? Evidence on early modern female readership is limited and problematic. Examining female book ownership through inventories can be misleading; women might have inherited books in which they had not been personally interested, whereas they might have read books they had exchanged, or books which appear only as the property of their husbands. Furthermore, rarely do inventories record books by name. Consequently, an indicator of female readership, so difficult to trace, has often been sought in dedications and addresses to women. However, taking this evidence at face value can be equally hazardous. As Helen Hackett has suggested for English Renaissance romance, addresses to women do not necessarily furnish evidence that the readership actually consisted of women; they might indicate the authors' wish that their works to be perceived as directed to a female readership, exciting male readers with the idea that they "penetrate the private space of a woman's bedchamber or closet where she is supposed to indulge in such reading." 52

In the Italian context, Anne Jacobson Schutte and Gabriela Zarri have suggested that vernacular devotional literature was associated with a female reading public already from the late fifteenth century. ${ }^{53}$ This view has been also largely based on proems and dedications, but is further substantiated by Danilo Zardin's and Paul Gehl's studies on book circulation in convents. ${ }^{54}$ 
Conduct books focusing on female domestic duties were also often dedicated to women, and it can be claimed that they had a female readership. ${ }^{55}$ Another indicator of women's readings can be female authorship. Virginia Cox has suggested that women writers' interest in chivalric poetry may indicate female readers' concern for them too. ${ }^{56}$ Similarly, the emergence of a number of poetesses modeling themselves on Vittoria Colonna's and Veronica Gambara's Petrarchist lyric in sixteenth-century Italy suggests learned women's engagement with poetry, especially that of Petrarch, who according to Dolce provided ideal feminine reading in which women "troveranno insieme con le bellezze della volgar Poesia \& della lingua Thoscana esempio d'honestissimo \& castissimo amore" (will find both the beauty of the vernacular poetry and Tuscan language and an example of the most honest and chaste love). ${ }^{57}$

It is plausible to suggest that women, especially from the middle and upper classes, were interested in works discussing female superiority. Elite women's interest in such works is further substantiated by examples where the dedicatee is explicitly referred to as having commissioned the work. Girolamo Borro's dedication of the Ragionamento della perfettione delle donne (1561) suggests such a role for Isabetta Cibo della Rovere: "quando voi illustrissima Signora, Marchesa, mi comandaste, che io scrivessi tutto quello, che allo improviso si disse della vertù, e grandezza delle Donne ..." (when you, most Illustrious Signora Marchesa, commanded me to write all about what could spontaneously be said about women's virtue and greatness ...). ${ }^{58}$ Women's interest in the controversy about them is also demonstrated by their participation in it as writers. During the course of the sixteenth century, prowoman arguments featured in several women's works. In Discorso sopra tutti i primi canti di Orlando Furioso (1549), Laura Terracina attacked misogynist rhetoric in her polemical poems Chi nemico è di donna, in altro a cura and $A$ gl'huomini nimici delle donne. In a similar vein, in Tullia d'Aragona's philosophical dialogue on love, Dialogo della infinità di amore (1547), the female speaker, Tullia herself, defended women and questioned the dominant misogynist discourse. Both works were published by Giolito. From a different point of view, in her Lettere familiari a diversi ${ }^{59}$ Veronica Franco pointed out the dangers to which poverty exposed Venetian women, stigmatized the sexual abuse of poor girls, and gave a gloomy account of prostitutes' lives. Finally, in the later sixteenth century the first substantial female-authored defences of women were written by two Venetian women, Moderata Fonte (Modesta Pozzo) and Lucrezia Marinella. By contrast with male-authored literature defending women which has been criticized by modern scholars as rhetorical and superficial, Moderata Fonte's Il merito delle donne (1600) and Lucrezia Marinella's La nobilità et l'eccellenza delle donne, co'difetti et 
mancamenti de gli uomini (1600) have been seen as genuine attacks on the repressive mechanisms of gender order and have been thoroughly studied. ${ }^{60}$

Boccaccio's female readership, however, is more open to question. The appeal of Boccaccio's works for women was a literary commonplace originating in Boccaccio himself, who dedicated De mulieribus claris to Andrea Acciaiuoli, Countess of Altavilla, and addressed both the Decameron and Fiammetta to women readers. In the sixteenth century, editions of Boccaccio's works were often dedicated to women or addressed female readers. Tizzone Gaetano di Pofi dedicated La Fiammetta (1524) to Dorothea [sic] Gonzaga, Marchioness of Bitonto, and Francesco Sansovino the Ameto, Comedia delle Ninfe Fiorentine (1545) to the poetess Gaspara Stampa. Giuseppe Betussi, in his dedication of the Libro di M. Gio. Boccaccio delle Donne Illustri (1558) to Camilla Pallavicina, Marchioness of Corte Maggiore, wrote that he translated Boccaccio's De mulieribus claris "beneficio non de gli huomini studiosi, \& letterati, ma delle donne nobili, \& virtuose" (not for the benefit of the studious and learned men but for the noble and virtuous ladies). At the same time, Boccaccio's works, especially the Decameron, were broadly regarded as pernicious readings for women. According to Lando, the Decameron was known as a "mal essempio alle honeste fanciulle, alle caste matrone" (bad example to honest girls, chaste ladies). ${ }^{61}$ Although these contradictory views might reflect a conflict between the contemporary cultural norms about female morality and the commercial significance of female readers, they can also be seen as two sides of the coin, of a rhetorical game between male authors and readers. Interestingly, even the same writers often adopted different views on Boccaccio. Dolce, who in the Dialogo della institution maintained that "tra quelli [libri], che [le donne] si debbono fuggire, le Novelle del Boccaccio terranno il primo luogo" (among those [books] that [women] have to avoid, Boccaccio's Novellas are in the first place), ${ }^{62}$ was the editor of Il Decamerone (1552) which Giolito suggested as pleasant feminine reading, maintaining his dedication of the 1546 edition.

Tracing Giolito's subsequent publishing activity in relation to the sociocultural developments of the later sixteenth century may allow us some glimpses into his publishing strategies in the 1540s and 1550s (aimed at a female clientele), and insight into whether or not his real intentions differed from the ostensible wish to attract a female readership. One of the most important consequences of the Catholic Reformation for the intellectual world of Venice and the rest of Italy was the implementation of the first generally accepted Index of Prohibited Books in 1564. Following Paul IV's Index of Prohibited Books of 1559, which had not been enforced due to the Pope's death and its unpopularity even in high Church circles, the Tridentine Index 
of Prohibited Books of 1564 prohibited not only heretical works but also those held to be lascivious or obscene, aiming at the broader moral reform of the readers. ${ }^{63}$ Under such circumstances, Venetian publishers gradually began to avoid secular vernacular literature, which risked being regarded as heretical, anticlerical, or immoral, and thus prohibited or allowed only after expurgation (such as Boccaccio's Decameron), a time-consuming and costly procedure. A parallel shift in the readers' preferences, within the new religious and moral climate, may have equally affected publishers' decisions. The effect of these developments was to give religious literature a prominent place in publishing output. ${ }^{64}$

Although the Index of Prohibited Books did not attack literature relating to the woman question as a whole, the broader post-Tridentine climate seriously affected it. As the sixteenth century progressed and religious preoccupations dominated intellectual life, literature defending women gradually waned, became more conventional and repetitive, and lost some of its social references; it was dealt with by lesser-known writers, shifted to obscure printing houses of smaller towns, or was limited to certain Courts. Significant exceptions to the rule were the works of Moderata Fonte and Lucrezia Marinella. However, on the whole, the focal point of the debate about women shifted now from "woman as autonomous entity" to women's position in the family and their religious education. This shift is manifested in the domination of religious conduct books for women and treatises on marriage and domestic economy in the later sixteenth century. This literature underlined women's domesticity, idealized female chastity, and explicitly excluded women from the public role which some works of the first half of the century had at least potentially suggested for them. ${ }^{65}$

Giolito soon adapted to the new situation. In the second half of the century, he, and from 1578 his descendants, continued to publish vernacular literature for the lay reader, but now focusing on devotional works for readers who lacked higher theological education. ${ }^{66}$ However, the Giolito company continued to appeal to women readers, albeit in a different context: with vernacular devotional works, hagiographies (especially of female saints), Mariological texts, and handbooks on Christian doctrine. Mostly written by clerics, devotional vernacular literature was mainly meant for tutorial use in convents, female institutions, schools of Christian doctrine, or in the family. From the 1560s Giolito no longer published texts relating to the controversy about women, and, although the Giolito company continued to issue new editions of Boccaccio, none of them was dedicated to women after 1546, apart from reprints. 
As with literature defending women, and Boccaccio, hagiographies of female saints and Mariological literature were frequently dedicated to women, now often nuns. Oratio Guarguanti's Eccellenze di Maria Vergine (1586) was dedicated to the Duchess of Savoia, and the friar Giovanni Lanspergio's Vita della beata vergine Gertruda (1588) to the nun Lucentia Farnese. Lanspergio's Libro della spiritual gratia, delle rivelationi, e visioni della beata Mettilde vergine (1588) was dedicated by the translator Ballardini to Eleonora, Duchess of Mantova and Monferrato, and Grand Duchess of Austria. The Franciscan Bartolomeo Meduna's Vita della gloriosa Vergine Maria (1574) was dedicated to the same woman by Giovanni Giolito, Gabriel's son. ${ }^{67}$ Religious education handbooks were meant for both men and women, such as Don Giovanpaolo da Como's Iesus Maria (1567). As its title indicates it contained "bellissimo et devotissimo dialogo ... per amaestrar i figliuoli mascoli e femine, secolari e religiosi, donne \& huomini, che non sanno, la institutione delle cose della fede, del timor d'Iddio, delli santi commandamenti d'Iddio, delli precetti \& santi sacramenti della Santa Chiesa" (most beautiful and devout dialogue ... to instruct children, boys and girls, the laity and the clergy, men and women, who do not know, the things relating to the faith, the fear of God, the holy commands of God, the precepts and the holy sacraments of the Holy Church).

Interestingly, not only did Giolito's titles change, but his self-image was also refashioned to adjust to the Catholic Reform spirit and the current readers' needs. In one of his latest publications, the Avvertimenti monacali (1575), a collection of spiritual writings, Giolito follows his old practice of advertising himself to a female audience, but now his identity has been transformed; instead of a devoted defender of women and a keen admirer of Boccaccio, the image of a pious man has emerged. Addressing the "vergini et spose di Christo" (Christ's virgins and brides), he writes:

Io, che da molt'anni in qua mi sento incredibilmente acceso di desiderio di giovar a ogni sorte di persone col mezzo delle mie stampe nelle cose spirituali allequali hoggi (mercè di Dio) gran parte del mondo si vede impiegata ... vi desse in un volume à legger tutto quello, che può aiutarvi ad arrivar al colmo, \& alla perfettione del vostro stato virginale.

I, who felt for years an extremely strong desire to be useful to people of all sorts with my publications on spiritual matters, in which nowadays many people are engaged (Thank God), ... offer you in one volume to read all these that can uplift you and help you to reach the perfection of your virginal state.

Despite the changes in the types of books, the Giolito company continued to appeal to a female reading public in the later sixteenth century, a circumstance that supports the view that the literature of the $1540 \mathrm{~s}$ and 
1550s not only appealed to certain communities of male readers, but was also intended for women readers. Therefore, Giolito's publishing strategies can be an indicator of women's reading preferences and the changes they underwent throughout the sixteenth century, although it is difficult to gauge the extent to which Giolito met his target to respond to the female readers' demands. This does not imply, however, that the authors' dominant ideology was passively received by women. Women's critical reading is manifested in the works of Moderata Fonte and Lucrezia Marinella in the late sixteenth century. In $\mathrm{Il}$ merito delle donne, Fonte rejected male-authored literature defending women, claiming that it was only male authors' "self interest and concern for their own honour" that prompted them to praise women. Similarly, in La nobilità et l'eccellenza delle donne, Marinella attacked Sperone Speroni's Dialogo della dignità delle donne (1542) and Torquato Tasso's Discorso della virtù feminile e donnesca (1582), both of which had been regarded by Marinella's predecessors and the writers themselves as substantial defences of women. ${ }^{68}$

An examination of the material form of the books can offer some further insights into their readership. Mostly published in small formats - either in octavo or duodecimo ${ }^{69}$ - they were quite cheap even by the Giolitian standards. Domenichi's Nobilità delle Donne in octavo cost 1 lira and 10 soldi in 1558, Terracina's Rime in octavo 8 soldi in 1560, Boccaccio's L'amorosa Fiammetta in octavo 12 soldi in 1586, and Laberinto d'Amore in duodecimo only 6 soldi in $1583 .{ }^{70}$ As Paul Grendler has argued for the Giolitian titles, "craftsmen and laborers could easily buy the less expensive titles ... A merchant or professional could afford a library of moderate size, and a patrician could support hundreds or thousands of volumes." ${ }^{11}$ However, although low prices made books accessible to a wider public, the low level of female literacy made it difficult for women to gain access to written culture. Despite the post-Tridentine efforts to provide boys and girls from the lower classes with an elementary education, the difference in literacy between men and women remained wide. For instance, 33 percent of the boys but only about 13 percent of the girls acquired basic literacy in Venice in $1587 .{ }^{72}$

The low level of female literacy suggests that literature relating to the controversy about women, and Boccaccio, appealed to middle- or upper-class women who were likely instructed in reading and writing either in convents or at home. ${ }^{73}$ Thus, instead of indicating the participation of female readers of lower social origins, the books' small format and low price rather determined their meaning and uses as pocketbooks to be read as a leisure pastime, being held in one's lap, as opposed to monumental luxurious volumes intended for decorating a prosperous library. ${ }^{74}$ Advertising Dolce's Dialogo della institution in 1545, Giolito stressed the convenience of the small format (picciolo 
volumetto). The Decameron was published by Giolito in several different formats - quarto, duodecimo, and sextodecimo - suggesting not only the different communities of readers it was meant for, but also the different meanings with which each form was invested. The Decameron's socially and culturally diverse communities of readers naturally responded differently to it, and its meaning (as a physical object) differed for each; ${ }^{75}$ for the sixteenth-century miller Menocchio it must have been a significant acquisition, ${ }^{76}$ whereas for a middle- or upper-class woman it was just a pocketbook, more expensive copies of which might have adorned the family library.

Devotional literature was closely related to the Catholic Reformers' programme for the religious instruction and moral reform of the laity and clergy. Often read aloud in convents, female institutions, or schools of Christian doctrine, which were reorganized and flourished in post-Tridentine Italy, this literature satisfied different needs. The reading practices were also different; instead of an individual activity aiming at pleasure, it was a joint effort for religious education and moral guidance. Illiterate women also participated in this culture of devotional literature by hearing it read aloud. Mostly addressing institutions rather than individuals, the Giolito company opted for a different format for devotional texts such as Lanspergio's, Meduna's, and Guarguanti's works and Avvertimenti monacali, which were published only in quarto and were of a higher price, judging from the 4 lire the Vita della beata vergine Gertruda cost in 1589.

Giolito's case sheds light on an important aspect of the social dynamic surrounding the controversy about women, that is women's cultural agency as readers. The commercialization, popularization, and competitiveness of the book industry in sixteenth-century Italy gave women the power to influence at least to some degree the discourse about them as readers and book consumers with commercial significance. In a two-way process, women readers were both influenced by the dominant discourse about them, and in turn affected it with their expectations. However, after the implementation of the Index of Prohibited Books, women's chances to influence the current cultural trends were reduced since their potential power as readers was inevitably limited.

Giolito's self-fashioning as a defender of women to appeal to specific communities of readers (both men and women) does not mean that his defence - in accordance with the contemporary cultural norms - was not sincere. What is interesting here is to explore how and why Giolito chose to project this particular public identity. Much remains to be learnt about female readers and their practices in early modern Italy. Unlike authors, readersparticularly women - have rarely left their own traces. However, as Giolito's case suggests, the relation between book production and readership may be 
fruitfully approached by a close examination of publishers' strategies and techniques, and the way they established themselves in the contemporary cultural scene.

\section{Department of History, Archaeology and Social Anthropology, University of Thessaly, Greece}

\section{Notes}

I am grateful to Chris Black for his constructive comments. I would also like to thank Mary Laven, Donald Spaeth, Costas Gaganakis, and G. Plakotos for their helpful advice on earlier drafts of this article. All translations are mine unless otherwise indicated. In quotes from the original Italian texts the spelling has been retained. Since dedications and proems in early modern Italian literature are often unpaginated, without, however, being longer than two or three pages, I do not give reference to the exact pages.

1. Gabriel Giolito de' Ferrari attracted scholarly interest for the first time in the late nineteenth century, when Salvatore Bongi's Annali provided information about the Giolito company's titles and the Giolito family's literary and social networks: Salvatore Bongi, Annali di Gabriel Giolito de' Ferrari da Trino di Monferrato stampatore in Venezia, 2 vols (Rome: Presso i Principali Librai, 1890-95). The Annali were later enriched and corrected by Paolo Camerini: Paolo Camerini, Notizia sugli Annali Giolitini di Salvatore Bongi (Padua: L. Penada, 1935). In 1977, Amedeo Quondam offered statistical evidence of the annual Giolitian production, and showed the changes Giolito's titles underwent in relation to the sixteenth-century Italian socio-cultural scene: Amedeo Quondam, “"Mercanzia d'onore' 'Mercanzia d'utile'. Produzione libraria e lavoro intellettuale a Venezia nel Cinquecento," Libri, editori e pubblico nell'Europa moderna, ed. Armando Petrucci (Rome: Laterza, 1977), pp. 53-104. More recently, another work on Giolito de' Ferrari's family offers interesting unpublished documents (contracts, book privileges, etc) as well as published catalogues, which allow us a better assessment of the history of Giolito's publishing house: Angela Nuovo and Christian Coppens, I Giolito e la stampa nell'Italia del XVI secolo (Geneve: Droz, 2005). Giolito's activities also figure in several studies on the Venetian or Italian publishing industry, book censorship, and intellectual life: Paul Grendler, The Roman Inquisition and the Venetian Press, 1540-1605 (Princeton, N.J.: Princeton University Press, 1977); Brian Richardson, Print Culture in Renaissance Italy. The Editor and the Vernacular Text, 1470-1600 (Cambridge: Cambridge University Press, 1994); idem, Printing, Writers and Readers in Renaissance Italy (Cambridge: Cambridge University Press, 1999); Claudia Di Filippo Bareggi, Il mestiere di scrivere. Lavoro intellettuale e mercato librario a Venezia nel Cinquecento (Rome: Bulzoni, 1988).

2. From the fifteenth century, a lively literary controversy about the nature, status, and roles of women flourished in Europe. Based on theological, philosophical, medical, and legal arguments, authors throughout Europe developed conflicting views on women, either reproducing the long-established medieval misogynist discourse and adjusting the traditional gender bias to the contemporary value systems and social practices, or challenging the dominant gender power relations and suggesting new pro-woman arguments, favouring women's physiological, intellectual, and moral equality, or even superiority, to men - perhaps even claiming social and political equality between men and women. The French term "querelle des femmes" was first used by nineteenth-century feminists, and 
originated in the so-called querelle de la Rose, the dispute between Christine de Pizan and Jean de Montreuil over Jean de Meung's misogynist Roman de la Rose in early fifteenth-century France. On the querelle de la Rose, see Charity Willard, Christine de Pizan. Her Life and Works (New York: Persea Books, 1984). On the controversy about women in Italy, see Conor Fahy, "Three early Renaissance treatises on women," Italian Studies 11 (1956), pp. 30-55; Francine Daenens, "Superiore perchè inferiore: il paradosso della superiorità della donna in alcuni trattati italiani del Cinquecento," Trasgressione tragica e norma domestica. Esemplari di tipologie femminili dalla letteratura Europea, ed. Vanna Gentili (Rome: Edizioni di Storia e Letteratura, 1983), pp. 11-49; Constance Jordan, Renaissance Feminism. Literary Texts and Political Models (Ithaca, N.Y. and London: Cornell University Press, 1990); Pamela Benson, The Invention of the Renaissance Woman. The Challenge of Female Independence in the Literature and Thought of Italy and England (University Park, Pa: Pennsylvania State University Press, 1992). Current scholarship's keen interest in the querelle des femmes is also reflected in a series of modern editions of early modern works defending women. The most complete project has been launched by the University of Chicago Press with "The Other Voice in Early Modern Europe," a series edited by Margaret L. King and Albert Rabil Jr.

3. Such as: a translation of Henricus Cornelius Agrippa von Nettesheim's Declamatio de nobilitate et praecellentia foeminei sexus (1544), Alessandro Piccolomini's L'orazione in lode delle donne (1545), Lodovico Dolce's Dialogo della institution delle donne secondo li tre stati, che cadono nella vita humana (1545), Ortensio Lando's Lettere di molte valorose donne, nelle quali chiaramente appare non esser ne di eloquentia ne di dottrina alli huomini inferiori (1548), and Lodovico Domenichi's La nobilità delle donne (1549).

4. Tullia d'Aragona's Rime (1547) and Dialogo della infinità di amore (1547), Laura Terracina's Rime (1548) and Discorso sopra tutti i primi canti d'Orlando Furioso (1549), and Vittoria Colonna's Rime (1552).

5. On the appropriate methods and techniques for a social history of the book and the politics of reading, see Roger Chartier, The Order of Books. Readers, Authors, and Libraries in Europe between the Fourteenth and Eighteenth Centuries, trans. Lydia Cochrane (Cambridge: Polity Press, 1993); Roger Chartier, The Cultural Uses of Print in Early Modern France, trans. Lydia Cochrane (Princeton, N.J.: Princeton University Press, 1987); Roger Chartier, "Texts, printing, readings," The New Cultural History, ed. Lynn Hunt (Berkeley: University of California Press, 1989), pp. 154-75; Roger Chartier, ed., The Culture of Print. Power and the Uses of Print in Early Modern Europe, trans. Lydia Cochrane (Cambridge: Polity Press, 1989); D. F. McKenzie, Bibliography and the Sociology of Texts (London: British Library, 1986); Robert Darnton, "First steps toward a history of reading," Australian Journal of French Studies 23 (1986), pp. 5-30.

6. Scholarship has often focused on the authorship of pro-woman literature. The intentions of the Renaissance authors defending women have been much debated and have raised conflicting views among scholars. Constance Jordan, for instance, sees a genuine protofeminist thought in the querelle des femmes, whereas Joan Kelly and, more recently, Pamela Benson have expressed serious doubts about the controversy's seriousness and sincerity, and have rather regarded it as a mere rhetorical game on the part of male authors: Jordan, pp. 2-9; Joan Kelly, "Early Feminist Theory and the Querelle des Femmes," in her Women, History, and Theory (Chicago and London: University of Chicago Press, 
1984), p. 75; Benson, pp. 1-8; on this debate, see also Linda Woodbridge, Women and the English Renaissance: Literature and the Nature of Womankind, 1540-1620 (Urbana: University of Illinois Press, 1984).

7. On Giovanni Giolito's publishing activity, see Giuseppe Dondi, "Giovanni Giolito editore e mercante," La Bibliofilia 69 (1967), pp. 147-89.

8. Bongi, vol. 1, pp. xiv-xxii, lxviii-lxxi, lxxxi-lxxxii.

9. Richardson, Print Culture, p. 90.

10. Grendler, The Roman Inquisition, pp. 3, 6 .

11. On the growth of print in Europe, see Rudolf Hirsch, Printing, Selling and Reading 1450-1550 (Wiesbaden: Harrassowitz, 1967); Elisabeth Eisenstein, The Printing Press as an Agent of Change: Communication and Cultural Transformations in Early Modern Europe (Cambridge: Cambridge University Press, 1979); idem, The Printing Revolution in Early Modern Europe (Cambridge: Cambridge University Press, 1983); on Italy, see Richardson, Printing, Writers and Readers; idem, Print Culture; on Venice, see Peter Burke, "Early modern Venice as a center of information and communication," Venice Reconsidered: the History of Civilization of an Italian City-State, 1297-1797, ed. John Martin and Dennis Romano (Baltimore and London: Johns Hopkins University Press, 2000), pp. 389-419.

12. On the Venetian poligrafi, see Tom Nichols, "Tintoretto, prestezza and the poligrafi: a study in the literary and visual culture of Cinquecento Venice," Renaissance Studies 10 (1996), pp. 72-100; Giovanni Aquilecchia, "Pietro Aretino e altri poligrafi a Venezia," in Storia della Cultura Veneta dal Primo Quatrocento al Concilio di Trento, 6 vols (Vicenza: Neri Pozza, 1976-86), vol. 3/II, pp. 61-98; Bareggi, Il mestiere di scrivere; Quondam, pp. 101-3; Paul Grendler, Critics of the Italian World, 1530-1560. Anton Francesco Doni, Nicolò Franco \& Ortensio Lando (Madison and London: University of Wisconsin Press, 1969), pp. 10-4, 65-9.

13. Richardson, Print Culture, pp. 96-8, 109-22.

14. Grendler, The Roman Inquisition, pp. 13-4.

15. Bongi, vol.1, pp. lv-lvi.

16. For a modern English edition, see Henricus Cornelius Agrippa, Declamation on the Nobility and Preeminence of the Female Sex, ed. and trans. Albert Rabil Jr. (Chicago and London: University of Chicago Press, 1996). On Agrippa's work, also see Barbara Newman, "Renaissance feminism and esoteric theology: the case of Cornelius Agrippa," Viator 24 (1993), pp. 337-56.

17. Henrico Cornelio Agrippa de la nobiltà, e preeccellentia del feminile sesso a la signora Margarita Augusta. Principe di Austria, e di Borgogna ([Venice], [1530]).

18. On the significance of the visual space of the books' preliminary materials: Chartier, The Order of Books, pp. 43-7.

19. Such as: the dedication of Girolamo Borro's Ragionamento della perfettione delle donne (Lucca: Busdragho, 1561) to Isabetta Cibo della Rovere, Marchioness of Massa; Tommaso Garzoni's Le vite delle donne illustri della scrittura sacra (Venice: Gio Domenico Imberti, 1588) to Margarita Estense Gonzaga, Duchess of Ferrara; Hercole Marescotti's Dell'eccellenza della donna (Fermo: Servitoio de' Monti, 1589) to Flavia 
Peretti Orsina; and Cristofano Bronzini's Della dignità et nobilità delle donne (Florence: Zanobi Pignoni, 1622) to Maria Maddalena d'Austria, Archduchess of Tuscany.

20. On literary patronage in early modern Italy, see Richardson, Printing, Writers and Readers, pp. 51-7.

21. On Giolito's detachment from traditional patronage mechanisms, also see Quondam, pp. 93-100.

22. Giolito belonged to the so-called "printers-publishers" who owned a press and financed most of their printing activities: Richardson, Printing, Writers and Readers, p. 34.

23. Della nuova scielta di lettere di diversi nobilissimi huomini, et eccelentissimi ingegni ... con un discorso della commodità dello scrivere di M. Bernardino Pino, 4 vols (Venice: [Aldus], 1574), Libro Secondo, pp. 336-37.

24. For a modern edition, see Marie-Françoise Piéjus, "L'orazione in lode delle donne di Alessandro Piccolomini," Giornale Storico della Letteratura Italiana 170 (1993), pp. 524-51. On the Intronati's relations with Sienese women, see Conor Fahy, "Women and Italian Cinquecento literary Academies," in Women in Italian Renaissance Culture and Society, ed. Letizia Panizza (Oxford: University of Oxford European Humanities Research Centre, 2000), pp. 438-52.

25. For a modern edition, see Alessandro Piccolomini, La Raffaella, ovvero Dialogo de la bella creanza de le donne, ed. Giancarlo Alfano (Rome: Salerno, 2001). Piccolomini's dialogue appeared in Italian seven times in the sixteenth century. It was also translated several times into French: Daniela Costa, “'La douceur de ce monde.' Le traduzioni francesi della 'Raffaella, o Dialogo della bella creanza delle donne' di Alessandro Piccolomini," Studi Francesi 40 (1996), pp. 233-39; Claude La Charité, "Le Dialogo de la bella creanza de le donne (1539) d'Alessandro Piccolomini et ses adaptateurs français," Renaissance and Reformation 23 (1999), pp. 43-58.

26. Piéjus, "L'orazione in lode delle donne," pp. 535-36; Ian Maclean, Woman Triumphant. Feminism in French Literature 1610-1652 (Oxford: Clarendon Press, 1977), p. 195.

27. Peter Burke, “The Renaissance dialogue," Renaissance Studies 3 (1989), pp. 1-12.

28. See especially Piccolomini's proem addressing "quelle donne che leggeranno."

29. Alessandro Piccolomini, De la institutione di tutta la vita de l'huomo nato nobile e in città libera (Venice: Hieronymum Scotum, 1542), fols 203 ${ }^{\mathrm{r}}-204^{\mathrm{r}}, 215^{\mathrm{v}}$. Also on the work, see Conor Fahy, "Love and marriage in the Institutione of Alessandro Piccolomini," Italian Studies presented to E. R. Vincent, ed. C. Brand, K. Foster and U. Limentani (Cambridge: Heffer, 1962), pp. 121-35.

30. Richard Samuels, "Benedetto Varchi, the Accademia degli Infiammati, and the origins of the Italian academic movement," Renaissance Quarterly 29 (1976), pp. 599-634.

31. In 1553, Girolamo Ruscelli openly criticized Dolce for having plagiarized Vives: Girolamo Ruscelli, Tre discorsi a M. Lodovico Dolce (Venice: Plinio Pietrasanta, 1553), p. 48.

32. For a modern English edition: Juan Luis Vives, The Education of a Christian Woman, ed. and trans. Charles Fantazzi (Chicago and London: University of Chicago Press, 2000).

33. Dolce, fols $21^{\mathrm{v}}-22^{\mathrm{r}}$ 
34. Ireneo Sanesi has suggested that the letters' author was Lando himself. Sanesi has also proposed Lando as the author of another work defending women, the Lettere à gloria del sesso feminile (Venice, 1552), published under the name of Lucretia Gonzaga da Gazuolo: Ireneo Sanesi, "Tre epistolari del Cinquecento," Giornale Storico della Letteratura Italiana 24 (1894), pp. 1-32.

35. On domestic life, see the letters by Portia Melita from Rome to her aunt Ginevra, Lucretia d'Este from Correggio to Emilia Mortella, Francesca Trivulza from Mantua to a certain Tessa, and Lucretia M. Contessa Beccaria to an anonymous recipient. On convent life, see the letters by Contessa di Monte l'Abbate from Venice to Sister A.B., and Emilia Brembata Solcia from Bergamo to Fulvia Rossa. On women's education, see the letters by Lucieta Soranza to Lucretia Masippa, Ippolita Crema to Fulvia Rulla, and Paula Trecca to Livia Portia. Ortensio Lando, Lettere di molte valorose donne (Venice: Gabriel Giolito de' Ferrari, 1549), fols $37^{\mathrm{r}-\mathrm{v}}, 102^{\mathrm{v}}, 2^{\mathrm{r}}, 96^{\mathrm{r}}, 63^{\mathrm{v}}, 52^{\mathrm{r}-\mathrm{v}}, 32^{\mathrm{r}}, 17^{\mathrm{r}}, 118^{\mathrm{r}}$.

36. Lando, Lettere, fol. $123^{\mathrm{r}}$.

37. Lando, Lettere, fols $136^{\mathrm{r}-\mathrm{v}}$.

38. Lando, Lettere, sig. xii.

39. For a modern edition, see Ortensio Lando, Paradossi, ciò̀ Sentenze fuori del comun parere, ed. Antonio Corsaro (Rome: Edizioni di storia e letteratura, 2000). On paradox in the Renaissance controversy about women, see Daenens, "Superiore perchè inferiore"; Anne Larsen, "Paradox and the praise of women: from Ortensio Lando and Charles Estienne to Marie de Romieu," Sixteenth Century Journal 28 (1997), pp. 759-74; Richard Carr, "The resolution of a paradox: Alexandre de Pontaymeri's response to the Querelle des femmes," Renaissance Studies 17 (2003), pp. 246-56.

40. Conor Fahy, "Un trattato di Vincenzo Maggi sulle donne e un'opera sconosciuta di Ortensio Lando," Giornale Storico della Letteratura Italiana 138 (1961), pp. 254-72.

41. Ortensio Lando, Oracoli de moderni ingegni si d'huomini come di donne, ne quali, unita si vede tutta la philosophia morale, che fra molti scrittori sparsa si leggera (Venice: Gabriel Giolito de' Ferrari e fratelli, 1550), fol. $3^{\text {r }}$.

42. Domenichi apparently refers to Galeazzo Capra's Della eccellenza e dignità delle donne (Rome: Francesco Minizio Calvo, 1525); Lodovico Martelli's "stanze in lode delle donne," in his Opere (Florence: Bernardo di Giunta, 1548); the third book of Baldesar Castiglione's Il libro del cortegiano (Venice: Aldo Romano \& Andrea d'Asola, 1528); Sperone Speroni's Dialogo della dignità delle donne and Dialogo in lode delle donne, both in his Dialoghi (Venice: Figli di Aldo, 1542); and Ieronimo della Rovere's Ad commendationem sexus muliebris oratio (Ticini [ie Pavia]: Joannes Maria Simoneta, 1540). The fourteenth-century poet Zanobi da Strada belonged to the literary circle of Boccaccio and Petrarch. He enjoyed the lifelong patronage of the Florentine Niccolò Acciaiuoli, brother of Andrea Acciaiuoli, Countess of Altavilla, to whom Giovanni Boccaccio dedicated his De mulieribus claris. Zanobi might have also written some work praising women. For Zanobi da Strada, see Medieval Italy. An Encyclopedia, ed. C. Kleinhenz, 2 vols (New York and London: Routledge, 2004), vol 2, 1174. Early modern Italian works defending women traditionally regarded Plutarch as a "defender of women," especially for his Mulierum virtutes: on this work, see P. A. Stadter, Plutarch's Historical Methods: an Analysis of the Mulierum Virtutes (Cambridge, Mass.: Harvard University Press, 1965). 
43. Giuseppe Passi, Dello stato maritale trattato (Venice: Iacomo Antonio Somascho, 1602), p. 54; Bronzini, Della dignità, Giornata Prima, p. 30.

44. Quondam, p. 63; Grendler, The Roman Inquisition, p. 4.

45. For a modern English edition, see Giovanni Boccaccio, Famous Women, ed. and trans. Virginia Brown (Cambridge, Mass. and London: Harvard University Press, 2003).

46. Such as: Alvaro de Luna's Libro de las claras e virtuosas mugeres (1446); Antonio Cornazzano's De mulieribus admirandis (c. 1467); Iacopo Filippo Foresti's De plurimis claris selectisque mulieribus (Ferrara: L. de rubeis de Valentia, 1497); Pietro Paolo Ribera's Le glorie immortali de' trionfi, et heroiche imprese d'ottocento quarantacinque donne illustri antiche, e moderne, dotate di conditioni, e scienze segnelate (Venice: Evangelista Deuchino, 1609); and Francesco Agostino Della Chiesa, Theatro delle donne letterate con un breve discorso della preminenza, e perfettione del sesso donesco (Mondovi: Giovanni Gislandi \& Gio Tomaso Rossi, 1620). On Boccaccio's influence, see also Virginia Brown's introduction in Boccaccio, Famous Women, pp.xx-xxi.

47. Baldesar Castiglione, The Book of the Courtier, ed. and trans. George Bull (London: Penguin Books, 1976), Castiglione, pp. 195, 201.

48. Girolamo Ruscelli, Lettura sopra un soneto dell' illustriss. signor marchese della Terza alla divina signora marchesa del Vasto. Ove con nuove et chiare ragioni si pruova la somma perfettione delle donne ... (Venice: Giovanni Grifio, 1552), p. 6.

49. Sperone Speroni, "Dialogo della dignità delle donne," in his Dialoghi (Venice: Roberto Meietti, 1596), p. 40.

50. Domenichi, p. 2.

51. Garzoni, p. 161 .

52. Helen Hackett, Women and Romance Fiction in the English Renaissance (Cambridge: Cambridge University Press, 2000), pp. 10-11.

53. Anne Jacobson Schutte, "Printing, piety, and the people in Italy: the first thirty years," Archiv für Reformationsgeschichte 71 (1980), p. 17; Gabriela Zarri, "La vita religiosa femminile tra devozione e chiostro: testi devoti in volgare editi tra il 1475 e il 1520," Frati minori tra '400 and '500: atti del XII convegno internazionale (Perugia: Università di Perugia, Centro di studi francescani, 1986), pp. 125-68.

54. Danilo Zardin, Donna e religiosa di rara eccellenza: Prospera Corona Bascapè, i libri e la cultura nei monasteri milanesi del Cinque e Seicento (Florence: Olschki, 1992); Paul Gehl, "Libri per donne. Le monache clienti del libraio Fiorentino Piero Morosi (1588-1607)," Donna, disciplina, creanza cristiana dal XV al XVII secolo, ed. Gabriela Zarri (Rome: Edizioni di storia e letteratura, 1996), pp. 67-80.

55. Such as: the second part of Giacomo Lanteri's Della economica (Venice: Vincenzo Valgrisi, 1560), dedicated to Lucretia Bóna Lanteri; Giulio Cesare Cabei's Ornamenti della gentil donna vedova (Venice: Cristoforo Zanetti, 1574) to the Venetian Ginevra Salviati de Baglioni; and Bernardo Trotto's Dialoghi del matrimonio e vita vedovile (Turin: Heredi del Bevilaqua, 1583) to Hippolita Scaravella Castelliera.

56. Virginia Cox, "Women as readers and writers of chivalric poetry in early modern Italy," Sguardi sull'Italia. Miscellanea dedicata a Francesco Villari dalla Society for Italian Studies, ed. Gino Bedani, Zygmunt Barański, Anna Laura Lepschy, and Brian Richardson (Leeds: Society for Italian Studies, 1997), pp. 134-45. 
57. Dolce, fol. $22^{\text {r }}$. On a discussion on female readership, see also Richardson, Printing, Writers and Readers, pp. 144-50.

58. The work, written under the pseudonym Telifilo Filogenio, is included in Girolamo Borro's Dialogo del flusso e reflusso del mare (Lucca: Busdragho, 1561), written under the pseudonym Alseforo Talascopio and dedicated to Isabetta's husband, Alberigo Cibo Malespina.

59. Veronica Franco, Lettere familiari a diversi (n.p., n.d.).

60. For modern English editions, see Moderata Fonte, The Worth of Women. Wherein is Clearly Revealed their Nobility and their Superiority to Men, ed. and trans. Virginia Cox (Chicago and London: University of Chicago Press, 1997); Lucrezia Marinella, The Nobility and Excellence of Women and the Defects and Vices of Men, ed. and trans. Anne Dunhill (Chicago and London: University of Chicago Press, 1999). Among several studies, see Ginevra Conti Odorisio, Donna e società nel seicento: Lucrezia Marinelli e Arcangela Tarabotti (Rome: Bulzoni, 1979); Patricia Labalme, "Venetian women on women: three early modern feminists," Archivio Veneto 117 (1981), pp. 81-109; Adriana Chemello, "La donna, il modello, l'immaginario: Moderata Fonte e Lucrezia Marinella," in Nel cerchio della luna: figure di donna in alcuni testi del XVI secolo, ed. Marina Zancan (Venice: Marsilio, 1983), pp. 95-170; Prudence Allen, RSM and Filippo Salvatore, "Lucrezia Marinelli and Woman's Identity in Late Italian Renaissance," Renaissance and Reformation 16 (1992), pp. 5-39; Virginia Cox, "The single self: feminist thought and the marriage market in early modern Venice," Renaissance Quarterly 48 (1995), pp. 513-81; Adriana Chemello, "The rhetoric of eulogy in Lucrezia Marinella's La nobilità et l'eccellenza delle Donne," Women in Italian Renaissance, ed. Panizza, pp. 463-77; Paola Malpezzi Price, Moderata Fonte. Women and Life in Sixteenth-Century Venice (Madison and London: Fairleigh Dickinson University Press and Associated University Presses, 2003).

61. From Lando's twenty-seventh paradox, Che l'opere del Boccaccio non sieno degne d'esser lette, ispetialmente le dieci giornate: Ortensio Lando, Paradossi, cioè sententie fuori del comun parere (Lyon: Gioanni Pullon da Trino, 1543), sig. M6.

62. Dolce, fol. $22^{\text {r. }}$.

63. "Libri, qui res lascivas, feu obscoenas ex professo tractant, narrant, aut docent cú non solum fidei, fed \& morum, qui huiusmodi librorum lectione facile corrumpi solent, ratio habenda sit, omnino prohibentur: \& qui eos habuerint, severe ab Episcopis puniantur" (Books which treat or derive from lascivious and immoral topics easily corrupt not only faith but also morals and should be forbidden; whoever have them should be punished strictly by the Bishops): Index librorum prohibitorum, cum regulis confectis per Patres à Tridentina Synodo delectos, auctoritate Sanctiss. D. N. Pii IIII. Pont. Max. comprobatus (Venice, 1564), fols $7^{\mathrm{r}-\mathrm{v}}$.

64. Grendler, The Roman Inquisition, pp. 115-17, 128-34.

65. Androniki Dialeti, The Debate about Women and Its Socio-Cultural Background in Early Modern Venice (unpublished PhD thesis, University of Glasgow, 2004), pp. 14-59.

66. According to Quondam, the largest production of religious literature coincided with the years between 1565-79, following the end of the Council of Trent, but already from 1555 there was a decline in literature, treatises, and dialogues: Quondam, pp. 89-91. See also Grendler, The Roman Inquisition, p. 133.

67. See also Richardson, Printing, Writers and Readers, p. 145. 
68. Fonte, The Worth of Women, p. 79; Marinella, The Nobility and Excellence of Women, pp. 136-39.

69. All editions of Della nobiltà, Dolce's Dialogo della institution, Lando's Lettere and Domenichi's La nobilità were in octavo. L'amorosa Fiammetta was published in octavo $(1542,1545,1558,1565,1584,1585,1586)$ and duodecimo $(1551,1562,1577,1578)$ and Laberinto d'Amore (Il Corbaccio) in octavo $(1545,1558)$ and duodecimo (1551, $1563,1564,1581,1582,1583,1597)$. Quite different was the case of Il Decamerone, published in quarto $(1538,1542,1546,1548,1550,1552)$, duodecimo $(1550,1552)$ and sextodecimo (1542).

70. These prices come from the Indice copioso, e particolare, di tutti i libri stampati dalli Gioliti in Venetia fino all'anno 1592 (n.p., n.d.), a catalogue published by Giovanni Paolo Giolito. The only known copy is preserved in Biblioteca Marciana (D. 193 D. 443).

71. Grendler, The Roman Inquisition, p. 14.

72. Paul Grendler, Schooling in Renaissance Italy. Literacy and Learning, 1300-1600 (Baltimore and London: Johns Hopkins University Press, 1989), p. 46.

73. On women's education in early modern Italy: Sharon Strocchia, "Learning the virtues. Convent schools and female culture in Renaissance Florence," in Women's Education in Early Modern Europe. A History, 1500-1800, ed. Barbara Whitehead (New York and London: Garland, 1999), pp. 3-46; Margaret King, Women of the Renaissance (Chicago and London: University of Chicago Press, 1991), pp. 164-72; Grendler, Schooling in Renaissance Italy, pp. 87-102.

74. On the traditional image of women holding books in their laps: Heidi Brayman Hackel, "'Boasting of silence': women readers in a patriarchal state," Reading, Society and Politics in Early Modern England, ed. Kevin Sharpe and Steven Zwicker (Cambridge and New York: Cambridge University Press, 2003), pp. 101-21, 109-11. On pocketbooks: Armando Petrucci, "Alle origini del libro moderno. Libri da banco, libri da bisaccia, libretti da mano," Italia Medioevale e Umanistica 12 (1969), pp. 295-313.

75. On the popularity of the Decameron, and the different communities of readers Venetian and Florentine publishers appealed to, see Brian Richardson, "Editing the Decameron in the sixteenth century," Italian Studies 45 (1990), pp. 13-31.

76. Carlo Ginzburg, The Cheese and the Worms. The Cosmos of a Sixteenth-Century Miller, trans. John and Anne Tedeschi (Baltimore: Johns Hopkins University Press, 1992), pp. 29, 50 . 